\title{
MUSYAWARAH MUFAKAT ATAU PEMILIHAN LEWAT SUARA MAYORITAS? DISKURSUS POLA DEMOKRASI DI INDONESIA
}

\author{
Oleh: Dessi Permatasari* dan Cahyo Seftyono**
}

\begin{abstract}
Democracy is the most popular system in our political discourse, not only in the global world but also in Indonesia. Democracy presents the common interest of people. Using all the infra-structure and supra-structure, the people interest could be contested as a government policy. The government policy, in Indonesia, has been produced in two mechanisms: Musyawarah Mufakat and Majority vote. Both of them based on our value called Pancasila. With the problem in democracy including space and number of people, musyawarah mufakat sometime replace in another process like majority vote. The example for majority vote is election, in national both in national scale and local scale such as Citi, Residence, and Province. But in other place musyawarah mufakat also perform in the making of policy in legislative level. In some case, the decision of discourse for government problems was decided by musyawarah mufakat. So, in this case, Musyawarah mufakat and Majority vote are same in the range of democracy system. Both of them also have fundamental reason that has fundamental reason as implementation of Pancasila as national value.
\end{abstract}

Keywords: Democracy, Musyawarah Mufakat, Majority Vote, Pancasila

\section{PENDAHULUAN}

Economic Intelligent Unit (EIU) lewat rilis dua tahunannya mengeluarkan laporan terkait indeks demokrasi. EIUmenyebutkan bahwa seluruh negara di dunia ini memiliki kecenderungan menuju pemerintahan yang demokratis. Mulai dari Amerika Serikat sampai RRC, Kuba, dan bahkan eks- Uni Soviet, semua mengklaim menganut demokrasi, meskipun pada kenyataannya pelaksanaan demokrasi tersebut berada pada level yang berbedabeda (EIU, 2013; Huntington, 1984). Perbedaan ini antara lain disebabkan adanya jarak konseptual antara pemikiran kaum individualis dan kolektivis. Kaum libelaris-individualis menganggap rakyat yang berdaulat adalah bersifat individu yang otonom, sedangkan kaum kolektivis dan komunitas menganggap rakyat yang berdaulat itu dalam pengertian kolektif dan totaliter (totalitarian). Upaya mencari jalan tengah diantara kedua pandangan ini terus diupayakan orang tetapi hasilnya ialah makin beragamnya cara umat manusia mempraktikan ide demokrasi itu sendiri. Demokrasi tidak hanya dinilai pada aspek partisipasi politik semata, melainkan juga pada pelaksanaan pemerintahan serta efektifitas kebijakan (Dahl, 1994; EIU, 2013).

Begitu juga yang tengah terjadi di Indonesia dimana, sebagai Negara yang menganut sistem demokrasi dalam

\footnotetext{
*Mahasiswa pada Program Studi Pancasila dan Pendidikan Kewarganegaraan Jurusan Politik dan Kewarganegaraan, Universitas Negeri Semarang. Alamat email: dessi.permatasarii@gmail.com.

***Dosen pada Program Studi Ilmu Politik, Jurusan Politik dan Kewarganegaraan Universitas Negeri Semarang.
} 
pelaksanannya belum dilakukan secara sempurna. Masih terdapat kekurangan dalam penyelenggaraan Negara terutama dalam pengambilan keputusan yang dilakukan oleh lembaga-lembaga negara. Sistem demokrasi belum sepenuhnya dapat dijalankan dan sesuai dengan pandangan hidup dan ideologi negara indonesia yaitu pancasila. Adanya pertentangan antara sistem demokrasi yang dijalankan dengan pancasila ini disebabkan Indonesia masih meniru demokrasi ala barat. Diskursus peran Pancasila ini misalnya dapat dilihat dari pandangan Morfit tentang Pancasila sebagai ideologi yang dalam politik Indonesia sangat kuat digunakan sebagai alat politik ketika jaman orde baru (Morfit, 1981).

Salah satu contohnya cara pengambilan keputusan yang dilakukan oleh lembaga-lembaga negara itu seharusnya bersumber pada sila ke-4 dari Pancasila yang dapat dilihat pada pembukaan UUD 1945. Yang berbunyi "Kerakyatan yang dipimpin oleh hikmah kebijaksanaan dalam permusyawaratan perwakilan". Akan tetapi kenyataanya sering dilakukan voting atau dengan suara terbanyak tanpa dilakukan musyawarah mufakat terlebih dahulu. Cara mengambil keputusan itu disebut musyawarah untuk mufakat.
Kesulitan menemukan titik temu penyelesaian masalah melalui musyawarah mufakat misalnya adalahkesulitan untuk semua orang akan setuju mengenai suatu masalah, karena tiap orang dan golongan berbeda kepentingan, sehingga mungkin saja pada suatu saat terjadi bahwa sekelompok kecil menyatakan tidak setuju. Dalam hal mufakat tidak tercapai, maka diusahakan untuk mengadakan kembali musyawarah, sehingga diharapkan bahwa akhirnya kelompok kecil ini akan menyetujui pendapat yang terbanyak.

Menyadari bahwa kemungkinan mufakat akan mengalami kesukaran dalam praktek karena heterogennya masyarakat Indonesia sekarang, maka Undang-Undang Dasar 1945 memberikan alternatif lain untuk mengambil keputusan seperti dirumuskan dalam pasal 2 ayat 3, pasal 6 a dan pasal 37, yaitu suatu keputusan yang diambil dapat dilakukan dengan suara terbanyak. Dengan demikian UndangUndang Dasar 1945 mengenal dua macam cara mengambil keputusan dalam rangka pelaksanaan demokrasi. Khususnya berkaitan dengan kebebasan dalam berpendapat (freedom of speaking). Adanya dualisme dalam pengambilan keputusan oleh lembaga-lembaga negara pada UUD 1945 yaitu dengan musyawarah untuk mufakat dan dengan suara yang terbanyak. Dalam hal ini, pemilihan 
dengan suara terbanyak lebih sering digunakan dalam pengambilan keputusan yang bersifat praktikal (Budiana, 2009; Fahmi, 2010)

\section{Dasar Pelaksanaan Demokrasi di} Indonesia: Sebuah Perspektif Pancasila

Demokrasi secara popular dimaknai sebagai rakyat berkuasa atau goverment by the people (kata Yunani demos berarti rakyat, kratos/kratein berarti kekuasaan/berkuasa). Demokrasi merupakan suatu pemerintahan dimana rakyat ikut serta memerintah. Baik secara langsung sebagaimana yang diungkap Olken dalam risetnya di Indonesia (Olken, 2010) maupun secara tidak langsung karena rakyat diwakilkan atau demokrasi tidak langsung, sebagaimana tulisan O’Donnell mengenai delegative democracy (O’Donnell, 1994), yang terdapat dalam negara-negara modern. Pendapat-pendapat popular tersebut bersinggungan dengan apa yang sudah dikemukanan oleh Schmitter dan Karl (1991) dalam artikelnya yang berjudul 'What democracy is.. and is not'. Konsep pemerintahan demokrasi adalah sebuah sistem yang menghubungkan dengan intens antara 'rulers' dan 'ruled', pemimpin yang membuat kebijakan dan orang-orang yang menjalankan kebijakan (warga).
Demokrasi yang dianut Indonesia sendiri, yaitu demokrasi berdasarkan Pancasila, masih dalam taraf perkembangan dan mengenai sifat-sifat dan ciri-cirinya terdapat berbagai tafsiran serta pandangan. Tetapi yang tidak dapat disangkal ialah bahwa beberapa nilai pokok dari demokrasi Indonesia tersirat di dalam UUD 1945.Diskursus peran Pancasila ini misalnya dapat dilihat dari pandangan Morfit tentang Pancasila sebagai ideologi yang dalam politik Indonesia sangat kuat digunakan sebagai alat politik ketika jaman orde baru (Morfit, 1981) atau setelahnya yang meskipun sudah mengalami era demokrasi yang lebih terbuka, Pancasila tetap sebagai panduan utama dalam berdemokrasi (Liddle, 1999).

Hal ini sangat jelas bahwa demokrasi di Indonesia telah diatur dalam UUD 1945 tepatnya terdapat pada pasal 1 ayat 2,2 ayat 3, 6a, pasal $22 \mathrm{E}$, dan pasal 37. Sehingga landasan pelaksanaan demokrasi di Indonesia sudah terjamin dalam konstitusi dan itu akan membawa dampak bagi kehiudupan Negara Indonesia terutama dalam bidang hukum. Sebagai Negara hukum sekaligus menganut sistem demokrasi, negara Indonesia harus memiliki ciri-ciri sebagai rechtstaats yaitu:

a. erlindungan konstitusional, dalam 
arti bahwa konstitusi selain menjamin hak-hak individu, harus menentukan pula cara prosedural untuk memperoleh perlindungan atas hak-hak yang dijamin,

b.

adan kehakiman yang bebas dan tidak memihak (independent and impartial tribunals),

c.

emilihan umum yang bebas,

d.

ebebasan untuk menyatakan pendapat,

e.

ebebasan untuk

berserikat/berorganisasi dan

beroposisi,

f.

endidikan kewarganegaraan (civic education).

Menurut International Commission of Jurists dalam konferensinya di Bangkok perumusan yang paling umum mengenai sistem politik yang demokratis adalah "suatu bentuk pemerintahan di mana hak untuk membuat keputusan-keputusan politik diselenggarakan oleh warga negara melalui wakil-wakil yang dipilih oleh mereka dan yang bertanggung jawab kepada mereka melalui suatu proses pemilihan yang bebas" (a farm of goverment where the citizens exercise the same right the right to make political decision, but through representatives chosen by them and responsible to them through the process of free elections).Ini dinamakan 'demokrasi berdasarkan perwakilan' (Budiardjo, 2008). B

Demokrasi berdasarkan perwakilan yang mengutamakan terjaminnya hak-hak asasi golongan minoritas terhadap mayoritas ini dinamakan derRokrasi dengan hak-hak asasi yang terkandung. Henry B. Mayo (1960) memberi Kefinisi sebagai berikut, "Sistem politik yang demokratis ialah dimana kebijaksanaan umum ditentukan atas dasar młyoritas oleh wakil-wakil yang diawasi secara efektif olehrakyat dalam pemilihanpemilihan berkala yang didasarkan atas prinsip kesamaan poRtikdan diselenggarakan dalam suasana terjaminnya kebebasan politik".

Demokrasi itu kebebasan berpendapat dan menyatakan pandangan mengenai suatu hal memang diperbolehkan bahkan dianjurkan. Begitu juga mengenai pengambilan keputusan yang dilakukan oleh lembaga negara harus berdasarkan peraturan perundangundangan yang berlaku dalam hal ini UUD 1945. Contohnya MPR dalam mengadakan perubahan terhadap UUD harus dihadiri oleh sejumlah anggota agar dapat dikatakan sah yakni mengacu pada pasal 37 UUD 1945. Begitu juga dalam 
keputusan untuk memilih presiden dan wakil presiden harus mengacu kepada peraturan perundangan yang berlaku.

\section{Sistem Pengambilan Keputusan dengan}

\section{Musyawarah untuk Mufakat}

Apakah yang dimaksud dengan musyawarah untuk mufakat? musyawarah adalah suatu cara memecahkan suatu masalah. Dalam musyawarah setiap orang yang ikut bermusyawarah mempunyai kesempatan yang sama untuk meyatakan kepentingannya. Inti dari musyawarah adalah toleransi, sehingga tiap orang dan golongan akan bersikap menghargai pendapat orang lain dan golongan yang lain. Bagi orang dan golongan tersebut tidak ada pemaksaan terhadap kehendak ataupun keinginan, walaupun golongan tersebut merupakan golongan minoritas.

Poin yang hendak dicapai dengan musyawarah adalah mufakat. Namun itu bukan sembarang mufakat, karena mufakat itu harus didasarkan kepada kepentingan bersama untuk mewujudkan masyarakat adil dan makmur berdasarkan Pancasila. Oleh karena itu mufakat itdak boleh bertentangan dengan Pancasila, sebab mufakat itu harus dijiwai dan melaksanakan Pancasila. Mufakat dalam suatu keputusan adalah apabila semua anggota yang bermusyawarah menyetujuinya, jadi sama sekali tidak diadakan perhitungan suara yang setuju dan tidak setuju (Kusnardi \& Ibrahim,1983).Apabila dalam hal mufakat tidak tercapai maka diusahakan untuk mengadakan kembali musyawarah, sehingga diharapkan bahwa akhirnya kelompok kecil ini akan menyetujui pendapat yang terbanyak.

Musyawarah untuk mufakat bersumber kepada Hukum Adat. Dalam hal ini berarti cara pengambilan keputusan dengan musyawarah yang didasari dengan toleransi, dimana kepentingan bersama lebih diutamakan dari kepentingan individu atau kelompok. Konsepsi 'musyawarah mufakat' muncul dari tradisi kultural bangsa Indonesia (Koentjaraningrat, 1967) dan cenderung menampilkan proses yang alot dan relatif sulit untuk diterapkan dalam perpolitikan kontemporer kecuali dalam skala isu dalam skala kecil (Kawamura, 2011).

Kelemahan dari sistem ini adalah musyawarah untuk mufakat saja sebagai cara mengambil keputusan, akan berakibat suatu masalah akan dipecahkan dalam waktu yang lama, sehingga akan berlarutlarut. Dan apabila pihak minoritas tetap bersikap tidak setuju akan mengakibatkan keputusan tidak pernah dapat diambil. Dengandemikian pihak minoritas dapat memaksa untuk tidak tercapainya keputusan. Kekuasaan minoritas ini dapat menimbulkan "diktatorial minoritas" 
dalam arti kekuasaan dari sekelompok kecil yang menentukan segala sesuatunya.

Sebaliknya kelebihan dari musyawarah untuk mufakat adalah semua pihak akan merasa diukutsertakan dan dihargai pendapatnya, sehingga hasil yang dicapai dirasakan sebagai bagian dari kepentingannya. Hal ini tidak akan menimbulkan oposisi hanya sekedar koreksi untuk kepentingan bersama.

\section{Sistem Pengambilan Keputusan dengan Suara Terbanyak}

Pada keadaan sekarang sulit untuk dilaksanakan atau bahkan dibayangkan pun sangat sukar musyawarah mufakat dapat dijalankan dalam pengambilan keputusan. Apabila diteliti lagi sulit untuk semua orang akan setuju mengenai suatu masalah, karena tiap orang dan golongan berbeda kepentingan, sehingga mungkin saja pada suatu saat terjadi bahwa sekelompok kecil menyatakan tidak setuju. Dalam hal mufakat tidak tercapai, maka diusahakan untuk mengadakan kembali musyawarah, sehingga diharapkan bahwa akhirnya kelompok kecil ini akan menyetujui pendapat yang terbanyak.

Menyadari bahwa kemungkinan mufakat akan mengalami kesukaran dalam praktek karena heterogennya masyarakat Indonesia sekarang, maka Undang-Undang Dasar 1945 memberikan alternatif lain untuk mengambil keputusan seperti dirumuskan dalam pasal 2 ayat 3 , pasal $6 \mathrm{~A}$ dan pasal 37, yaitu suatu keputusan yang diambil dapat dilakukan dengan suara terbanyak.

Pasal 2 ayat 3 menyebutkan bahwa Majelis Permusyawaratan Rakyat mengambil keputusan dengan suara terbanyak, sedangkan pasal 6 A mengenai keputusan pemilihan presiden dalam pemilu dan pasal 37 menentukan bahwa Majelis Permusyawaratan Rakyat merubah Undang-Undang Dasar dengan 2/3 dari anggota Majelis Permusyawaratan Rakyat harus hadir dan harus disetujui dari sekurang-kurangnya lima puluh persen ditambah satu anggota dari seluruh anggota Majelis Permusyawaratan Rakyat.

Dalam Hukum Tata Negara dikenal beberapa macam keputusan dengan suara terbanyak. Suara terbanyak sederhana (simple mayority) yaitu keputusan yang diperoleh apabila yang setuju lebih banyak dari yang tidak setuju, dan yang setuju itu sekurang-kurangnya $1 / 2+1 . \quad$ Suara terbanyak mutlak (absolute mayority) yaitu apabila yang setuju jauh lebih banyak dari yang tidak setuju sehingga perbedaan antara yang setuju dan tidak setuju terlihat dengan jelas, dan suara terbanyak ditentukan (qualified mayority) yaitu jika Undang-Undang Dasar atau Undang-Undang atau Peraturan Tata Tertib suatu lembaga negara menentukan 
bahwa keputusan adalah sah apbila memenuhi syarat-syarat yang ditentukan, umpamanya seperti pasal 37 UndangUndang Dasar 1945 atau mungkin pula dengan $1 / 2+1$ atau untuk sahnya sidang ditentukan 2/3, sedangkan untuk sahnya keputusan ditentukan $1 / 2+1$.

Timbul pertanyaan suara terbanyak yang bagaimanakah yang dikehendaki oleh pasal 2 ayat 3 dan pasal 6 A. Karena pembuat Undang-Undang Dasar 1945 telah menentukan dalam pasal 37 suara terbanyak yang ditentukan yaitu $1 / 3 \times 2 / 3 \times 1 / 2+1$ dan ini khusus untuk perubahan Undang-Undang Dasar 1945 yang memerlukan syarat berat agar tidak setiap saat perubahan dilakukan, kecuali jika perubahan dirasakan sebagai kebutuhan multak dari sebagaian besar masyarakat, maka jelas hal ini tidak mungkin dipakai terhadap pasal 2 ayat 3 dan pasal 6 A. Untuk kedua pasal tersebut hanya mungkin dipakai suara terbanyak yang lebih mudah dari pasal 37, yaitu suara terbanyak biasa atau suara terbanyak mutlak.

Pengambilan keputusan dengan suara terbanyak di dasarkan pada Demokrasi Barat dengan sifat individualisme sebagai cirinya. Dalam suara terbanyak yang menonjol adalah kepentingan individu atau kelompok. Sehingga dalam suara terbanyak untuk menentukan suatu keputusan adalah sah cukup dengan menghitung suara yang setuju dan tidak setuju, dan apabila suara yang setuju lebih banyak dari yang tidak setuju maka keputusan adalah sah. Adanya sistem pengambilan keputusan dengan suara terbanyak tidak dapat dipungkiri bahwa para pembuat Undang-Undang Dasar 1945 yang berpendidikan Barat, tidak dapat melepaskan diri dari pengaruh demokrasi Barat. Salah satu contoh digunakannya sistem suara terbanyak pada pemilihan Presiden dan wakil presiden yang terdapat dua atau lebih calon Presiden dan calon wakil presiden. Oleh karena itu pasal 6 A ayat 4 menentukan bahwa presiden dan wakil presiden dipilih dengan suara terbanyak, begitu pula dalam hal merubah Undang-Undang Dasar 1945, sebagaimana diatur dalam pasal 37.

Akan tetepi sistem ini memiliki kelemahan yaitu apabila keputusan diambil hanya dengan suara terbanyak saja, kemungkinan yang akan timbul adalah bahwa golongan mayoritas akan selalu memaksakan kehendaknya kepada golongan minoritas. Golongan minoritas tidak akan pernah mempunyai kesempatan untuk menetapkan pendapat dan kehendaknya, apabila pendapatnya itu tidak disetujui oleh golongan mayoritas. Demikian besar kekuasaan golongan mayoritas, sehingga Alexis de Tocquivelle menyebutkan sebagai "Tirani Majoritas" sehingga dapat menimbulkan "Diktatorial 
Mayoritas". Sebaliknya kelebihan dari sistem dengan suara terbanyak adalah setiap keputusan dapat diakhiridalam waktu yang relatif jauh lebih pendek dari musyawarah mufakat (Kusnardi \& Hermaily Ibrahim, 1983).

\section{Pemetaan Sistem Pengambilan Keputusan yang Pernah Berlaku di Indonesia}

Negara-negara demokrasi modern pada dasarnya memiliki konsepsi perwakilan yang dilakukan menurut berbagai macam cara dan variasinya. Pada garis besarnya pembagian itu terdiri dari perwakilan dengan stelsel parlementer dan perwakilan dengan stelsel pemisahan kekuasaan.

Sebagai suatu negara yang menganut asas kedaulatan rakyat, negara Indonesia juga disebut sebagai negara demokrasi. Seperti yang telah diuraikan di awal bahwa dalam pengertian murninya rakyat secara keseluruhan ikut menentukan jalannya pemerintahan, dan yang demikian itu disebut sebagai demokrasi langsung. Pada umunya orang beranggapan bahwa pada jaman Yunani Kuno dan Rumawi Kuno terdapat demokrasi langsung sehingga Corry (1959) dalam bukunya "Democratic Goverment and Politics" menyatakan; "The ancient democracies were direct democracies. Each citize participated directly in making laws, and could expect to come to public office from time to time by lot or relation". Pernyataan tersebut kurang lebih berarti bahwa karena dalam city state atau polis terdapat perbedaan tentang siapa yang diseru warga kota, yang juga membawa perbedaan dalam haknya, maka yang terjadi disana sebenarnya bukan demokrasi yang murni tetapi suatu demokrasi yang terbatas.

Dalam masyarakat demokrasi modern sekarang ini memang dimana wilayah negara sudah begitu luas, jumlah penduduknya sudah banyak, dan tingkat kehidupannya sangat kompleks yang menimbulkan macam-macam spesialisasi, maka sukar untuk membayangkan bahwa demokrasi langsung dapat dipratekkan, sehingga memang sudah menjadi tuntutan jaman apabila demokrasi tidak langsung (demokrasi perwakilan) itu harus menggantikannya (Dahl, 1989; Merkel, 2004). Demokrasi tidak langsung atau yang sering disebut sebagai demokrasi perwakilan (representative democracy) karena rakyat tidak secara langsung menentukan jalannya pemerintahan, tetapi melalui wakil-wakilnya dalam lembaga legislatif. Jadi rakyat mewakilkan kepada wakil-wakilnya yang duduk di lembaga dewan untuk menentukan jalannya pemerintahan. Selain itu masih ada lembaga eksekutif dan yudikatif yang juga turut menyelenggarakan pemerintahan dalam mengambil keputusan harus 
berlandaskan dengan pancasila dan UUD 1945 serta peraturan lainnya yang berlaku.

Pengambilan keputusan yang seperti apa yang dilakukan oleh lembaga negara selama ini. Bagaimanakah pelaksanaannya? Sejak Dekrit Presiden 5 Juli 1959 sampai pada saat meletusnya Gerakan G30/SPKI maka baik di Dewan Perwakilan Rakyat maupun Majelis Permusyawaratan Rakyat keputusan diambil dengan musyawarah untuk mufakat. Landasan untuk itu telah diletakkan pada ketetapan MPR Sementara (MPRS) No. VIII/MPRS/1965, dimana ditentukan bahwa keputusan diambil dengan musyawarah untuk mufakat. Apabila musyawarah untuk mufakat tidak dapat dicapai, maka persoalannya diserahkan kepada pimpinan. Apabila pimpinan juga gagal mengambil keputusan, maka persoalan ditangguhkan sehingga akhirnya dapat ditiadakan.

Pada masa orde Baru di saat-saat MPRS melaksanakan sidang-sidang umum dan istimewa pada tahun 1966 dan 1967, hampir tidak ada pedoman yang tegas dalam bentuk ketetapan MPR tentang cara pengambilan keputusan. Baru kemudian pada sidang umum ke-V MPRS menetapkan ketetapan No. XXXVII/MPRS/1968 yang mencabut ketetapan MPR No. VIII/MPR/1965, dan menentukan bahwa keputusan diambil dengan musyawarah untuk mufakat, dan apabila ini gagal keputusan diserahkan kepada pimpinan dan kalau ini juga gagal maka keputusan diambil dengan suara terbanyak.

Secara singkat dapat dijelaskan bahwa sejak 5 Juli 1959 sampai sidang umum MPR pada bulan Maret 1978, di lembaga negara MPR dan DPR telah terjadi semacam konvensi dalam mengambil keputusan yaitu selalu dengan musyawarah untuk mufakat, kendati pun dengan suara terbanyak dimungkinkan. Dalam kurun waktu tersebut diperoleh kesan bahwa cara yang terakhir ini selalu dihindarkan. Kemudian ternyata konvensi itu tidak lagi dipratekkan sejak tahun 1978 di MPR , dan sejak 1979 di DPR. Yang pertama adalah pada waktu MPR membahas Garis-Garis Besar Haluan Negara dan Pedoman Penghayatan dan Pengamalan Pancasila (Ekaprasetia Pancakarsa) atau P4 pemungutan suara sebagai cara mengambil keputusan dilakukan oleh DPR dipenghujung tahun 1979 pada waktu membicarakan usul interpelasi anggota DPR dari fraksi Persatuan Pembangunan dan Fraksi Partai Demokrasi Indonesia tentang Normalisasi Kehidupan Kampus/Badan Koordinasi Kemahasiswaan (NKK/BKK). NKK/BKK ini justru saat ini menjadikan organisasi intra-kampus menjadi basis kekuatan politik modern (Jackson, 2005). 
$10 \quad \begin{aligned} & \text { JURNAL ILMIAH MIMBAR DEMOKRASI } \\ & \text { VOLUME 13, NOMOR 2, APRIL } 2014\end{aligned}$

Nampaknya cara penyampaian suara yang diperagakan oleh DPR di penghujung tahun 1979 dan oleh MPR pada tahun 1978 belumlah dapat dikatakan sesuai dengan asas suara terbanyak. Karena mengatur tempat duduk setiap anggota MPR dan DPR menurut fraksi dan kemudian suara diberikan dengan cara berdiri, untuk saat ini sama sekali tidak mencerminkan pendapat atau keyakinan setiap anggota lembaga negara tersebut. Walaupun belum dilakukan suatu penelitian, tetapi dari pengamatan yang telah dilakukan, diduga akan sangat tidak mungkin anggota suatu fraksi akan berbeda pendapat dengan fraksinya dalam forum seperti itu.

Perkembangan ketatanegaraan dalam masalah pengambilan keputusan untuk saat ini juga tidak jauh berbeda dengan dahulu. Walupun UUD 1945 telah mengalami amandemen sebanyak 4 kali tetapi kenyataannya baik musyawarah untuk mufakat maupun pemungutan suara dipraktekan kurang sesuai dengan jiwa dari kedua cara tersebut. Musyawarah untuk mencapai mufakat yang dipratekkan oleh DPR hampir mendekati kompromi. Sering kita membaca di surat kabar harianharian, golongan mayoritas terlalu banyak memberi, sedangkan golongan minoritas tidak bersedia untuk mundur dari prisinpnya. Sebaliknya pula kita mendengar bahwa salah satu kelompok memberikan harga mati tentang suatu masalah. Apabila dalam musyawarah untuk mufakat golongan minoritas telah dihadapkan kepada cara-cara yang tidak lagi mencerminkan inti musyawarah untuk mufakat, dan harapan untuk berhasil dalam pemungutan suara yang hasilnya sudah dapat diperkirakan sejak semula, maka satu-satunya cara untuk menyatakan sikapnya golongan minoritas akan melaksanakan 'walk out'. 'Walk out' adalah salah satu mekanisme kompromi politik yang mncul akibat dari deadlock dalam pemngambilan kebijakan yang kemudian memberikan waktu yang lebih lama untuk melakukan negosiasi (Hagan et.al., 2001)

Pada akhirnya yang menentukan adalah kedewasaan dalam berdemokrasi. Bahwa dengan musyawarah untuk mufakat pun mekanisme dapat berjalan secara baik, apabila ada kesadaran berdemokrasi dan tekad untuk mendahulukan kepentingan bersama dari pada kepentingan individu dan golongan. Dengan demikian maka kelemahan dari musyawarah untuk mufakat dapat dihilangkan begitu pula dalam hal suara terbanyak. Pihak yang kalah jangan sampai menjadi golongan oposisi yang destruktif, tetapi harus mengontrol demi kepentingan bersama. Untuk mencegah timbulnya oposisi destruktif tersebut, pada tahap pertama harus dilakukan dengan musyawarah. 
Dengan bermusyawarah dapatlah

diketahui alasan dari golongan yang tidak setuju, dan golongan tersebut akhirnya menyadari bahwa kepentingan bersama harus didahulukan diatas segala kepentingan baik individu maupun golongan. Sehingga golongan yang kalah dalam suara terbanyak dapat diharapkan akan bertindak sebagai seorang demokrat yang sejati.

\section{Kesimpulan}

Demokrasi adalah suatu pemerintahan dimana rakyat ikut serta memerintah (mederegeren), baik secara langsung yang terdapat pada masyarakat yang masih sederhana, maupun secara tidak langsung karena rakyat diwakilkan yang terdapat dalam negara-negara modern. Secara kultural, asas kehidupan bermasyarakat di Indonesia merupakan sebuah sistem yang dihasilkan atas konsensus bersama demi kebaikan bersama. Termasuk di dalamnya proses politik dan demokrasi. Demokrasi yang hidup di Indonesia adalah kekeluargaan, untuk mengabdi kepentingan bersama dalam mencapai tujuan yang sama. Salah satu wujudnya untuk mencapai keputusan dalam demokrasi yang berlaku di Indonesia, lazimnya dilakukan suatu musyawarah untuk sepakat atau mufakat. Hal ini muncul dari diskursus budaya yang muncul dari dialog masyarakat dalam rangka menyelesaikan masalah publik.

Realitas iklim demokrasi Indonesia dewasa ini tidak memungkinkan diadakannya musyawarah mufakat, dikarenakan proses politik yang semakin kompleks. Demokrasi, selain dihadapkan pada persoalan jumlah peserta politik, juga pada banyaknya pilihan-pilihan yang menyebabkan proses pengambilan keputusan sedemikian kompleks. Akibatnya, kita kemudian membutuhkan sebuah mekanisme di luar musyawarah mufakat, untuk menemukan solusi bersama yang lebih cepat dan efisien. Menyadari hal tersebut, Undang-Undang Dasar 1945 memberikan alternatif lain untuk mengambil keputusan yaitu dengan suara terbanyak atau mayoritas. Seperti yang dirumuskan dalam pasal 2 ayat 3 dan pasal 37 bahwa suara mayoritas dapat menentukan hasil dari suatu keputusan. Dengan demikian Undang-Undang Dasar 1945 mengenal dua macam cara mengambil keputusan dalam rangka pelaksanaan demokrasi.

Khususnya berkaitan dengan kebebasan dalam berpendapat (freedom of speaking) yaitu dengan musyawarah untuk mufakat dan dengan suara yang terbanyak. Pada titik ini, kebutuhan atas hak bersuara dan penghargaan atas hak individu sudah dapat dipenuhi dalam proses pengambilan keputusan. 
12 JURNAL ILMIAH MIMBAR DEMOKRASI

Karenanya, pemilihan dengan suara terbanyak dapat dikatakan sebagai proses yang demokratis, tanpa 'melanggar' kesepakatan kultural dan juga aturanaturan dalam kerangka Pancasila dan UUD 1945.

\section{DAFTAR PUSTAKA}

Asshiddiqie, Jimly(2005), Hukum Tata Negara dan Pilar-Pilar Demokrasi,Jakarta,Konstitusi Press.

Budiana, I.Nyoman. (2009), Reinterpretasi Sistem Pemilu sebagai Implementasi Kedaulatan Rakyat di Indonesia, Jurnal Konstitusi, Vol. 2 No. 1.

Budiardjo, Miriam(2008), Dasar-Dasar Ilmu Politik, Jakarta, Gramedia PustakaUtama.

Corry, J.A. and J.E. Hodgetta ( $2^{\text {nd }}$ ed.) (1959), Democratic Government and Politics, Toronto: University of Toronto Press.

Dahl, Robert (1989), Democracy and Its Critics, New Haven, CT: Yale University Press.

Dahl, Robert, (1994),

A Democratic Dilemma,

System Effectiveness versus

Citizen Participation, Political

Science Quarterly, Vol. 109 Issue 1.

Economic

Intelligent

Unit(2013),Democracy Index 2012,

Democracy at a Standstill. London: Economic Intelligent Unit.

Fahmi, Khairul (2010), Prinsip Kedaulatan Rakyatdalam Penentuan Sistem Pemilihan Umum Anggota Legislatif, Jurnal Konstitusi Vol. 7 No. 3.
Hagan, Joe D., Philip P. Everts, Haruhiro Fukui, John D. Stempel (2001), Foreign Policy by Coalition: Deadlock, Compromise, and Anarchy, International Studies Review, Vol. 3 No. 2.

Huntington, Samuel P. (1984), Will more Countries become Democratic?, Political Science Quarterly, Vol. 99 No. 2.

Ibrahim, Harmaily (1979), Majelis Permusyawaratan Rakyat, Suatu Tinjuan dariSudut Hukum Tata Negara, Jakarta, Sinar Bakti.

Jackson, Elisabeth (2005), 'Warring Words': Students and the State in New Order Indonesia, 1966-1998. ACT Canberra: Disertasi doktoral di Australian National University.

Kawamura, Koichi (2011), Consensus and Democracy in Indonesia: Musyawarah-Mufakat Revisited, IDE Discussion Paper No. 308.

Koentjaraningrat (ed.) (1967), Villages in Indonesia, Ithaca, NY: Cornell University Press.

Kusnardi, Moh. Dan Harmaily Ibrahim(1983),Hukum Tata Negara Indonesia,Jakarta, Pusat Studi Hukum Tata Negara Fakultas Hukum UI dan CV SinarBakti.

Liddle, RW (1999), Indonesia's Democratic Opening, Government and Opposition, Vol. 34 Issue. 1.

Mayo, Henry (1960), An Introduction to Democratic Theory, New York: Oxford University Press.

Merkel, W. (2004), Embedded and Defectiveness Democracy, Democratization, Vol. 11 No. 5. 
Morfit, Michael (1981), Pancasila: The Indonesian State Ideology According to the New Order Government, Asian Survey, Vol. 21 no. 8.

Olken, BA (2010), Direct Democracy and Local Public Goods: Evidence from a Field Experiment in Indonesia,
American Political Science Review, Vol. 104 No. 2.

O'Donnell, Guillermo (1994), Delegative Democracy, Journal of Democracy, Vol. 5 No. 1.

Schmitter, Philippe C. and Terry Lynn Karl (1991), What Democracy is ... and is not, Journal of Democracy Vol. 2 Issue 78 